\title{
Taoism with Vietnamese Mother Goddess Worshipping Belief
}

\author{
Nguyen Thi Mut \\ Faculty of Philosophy, University of Social Sciences and Humanities, Ho Chi Minh City, Vietnam \\ Email address: \\ mutnguyen87@gmail.com

\section{To cite this article:} \\ Nguyen Thi Mut. Taoism with Vietnamese Mother Goddess Worshipping Belief. International Journal of Philosophy. \\ Vol. 9, No. 3, 2021, pp. 148-153. doi: 10.11648/j.ijp.20210903.15
}

Received: July 24, 2021; Accepted: August 5, 2021; Published: August 11, 2021

\begin{abstract}
Taoism originated from China and has had a profound influence on Chinese culture. Today, the Taoist tradition is one of the five religious doctrines officially recognized by China. Taoism was introduced into Vietnam very early. During its existence and development in Vietnam, Taoism has had a relationship with and influence on many Vietnamese folk beliefs, including Mother Goddess worshipping. Mother Goddess worship is a Vietnamese folk belief, with a long history, adapting to changes in Vietnamese society. It has had a critical position in the spiritual activities of Vietnamese people. Mother Goddess worship not only has a special attraction but also poses various problems for many scientists and researchers in society. The study aims to find out the relation between Taoism with Vietnamese mother Goddess worshipping belief. Specifically, the study has explored the influence of Taoism on the system of Mother Goddess worship in Vietnam and the influence of Taoism on worshiping forms and human conceptions in Mother Goddess worship. To obtain research objectives, the author has used various research methods such as philosophical history, analysis - synthesis; compare - contrast to find out study results. Some discussions on preserving and promoting the values of Mother Goddess worship in Vietnam have been presented in the study.
\end{abstract}

Keywords: Taoism, Mother Goddess Worship, Belief, Vietnam

\section{Introduction}

Taoism (also known as Daoism) was introduced into Vietnam very early. Regarding determining when and how exactly Taoism spread into Vietnam, there has been no accurate historical source so far. According to many researchers' opinions, Taoism was introduced into our country in two ways: first, it followed in the footsteps of the invading force (the Chinese mandarins worship Taoism); second, it followed in the footsteps of the expatriates, persecuted by the ruling class of feudal China. Taoism quickly penetrated the lives of Vietnamese people, received and transformed by Vietnamese people, and became an inseparable part of the culture. During its existence and development in Vietnam, Taoism has had a relationship with and influenced many Vietnamese folk beliefs, including Mother Goddess worship belief. Mother Goddess worship has had a special position in the spiritual activities of Vietnamese people; it is a spiritual need of a part of the people that have existed in history and even today. "Mother" is an image and a symbol of the cultural and spiritual life of
Vietnamese people. Mother Goddess worship not only has a special attraction but also poses various problems for many scientists and researchers in society. Mother goddess worshiping belief not only meets the needs of spiritual life; it is also a phenomenon of rich and attractive folklore activities that attract people. People who come to Mother goddess worship belief also have empathy for cultural values and contribute to strengthening the sense of community of the Vietnamese people. The Mother Goddess worship belief is a unique cultural and spiritual phenomenon in the polytheistic folk belief system of the Vietnamese people. During the formation and development process, Mother Goddess worship belief has close relations and has interacted with other religions and beliefs such as Taoism.

The research of Taoism with the Vietnamese Mother Goddess worship belief has both scientific and practical significance in Vietnam today, contributing to clarifying the influence of Taoism on the spiritual life, as well as the richness of Vietnamese folk belief activities. 


\section{Literature Review}

\subsection{Origins of Taoism and Vietnamese Mother Goddess Worship}

Firstly, according to Laozi - Zhuangzi Thought, Early Taoism originated from the Laozi- Zhuangzi Thought of the Qin dynasty and had a relationship with the Yellow Emperor Taoism - a doctrine derived from the Taoism of Tac Ha region. Therefore, it is more or less mixed with some elements of Confucianism, Legalism, and other sects, but basically, Taoism is more closely associated with LaoziZhuangzi thought. During its existence and development, Taoism has considered Lao Tzu as the ancestor of the sect; his scriptures were true scriptures; especially his "Tao" was the theoretical core of Chinese Taoism. The first connotation of the concept of "Tao" in the Tao Te Ching is that "Tao" is the essence of the universe, producing all things. Tao Te Ching writes: "The Tao is like an empty container: it can never be emptied and can never be filled. Infinitely deep, it is the source of all things" [1] "The supreme good is like water, which benefits all of creation without trying to compete with it. It gathers in unpopular places. Thus, it is like the Tao [1] "The Tao gives birth to one, one gives birth to two, two gives birth to three, and three gives birth to all things" [2]. Thus, the Tao is what existed before heaven and earth, giving birth to all things. The word "Tao" here mainly refers to the cosmic being.

Second, according to wizard thought and the cult of God. The belief in God is central to Taoism- the main feature of Taoist beliefs. In ancient times, God was considered the lord of the universe. The power of emperors in the human world was considered the will of the gods. Politics, human morality, and the economic system were also regarded to be the will of Gods. Taoism inherited the worship and the rituals of sacrifice to the gods of the ancients. On that basis, Taoism has supplemented and developed many additional contents, thereby forming its norms and regulations. Our ancestors worshipped the gods to pray for blessings and overcome disasters and dangers. However, it is difficult for someone to know how those gods are and contact those gods. Therefore, there appeared a "medium" who specialized in making contact with the gods. These people are said to have mystical powers when they can communicate with the gods, and mobilize the power of the gods to help people overcome disasters and dangers in life. For that reason, the sacrifice to gods was more necessary. The sacrifice to some typical gods has developed into an important festival in the folk religious life of Vietnamese people. However, the magic at that time did not combine with Taoism; there was no pontiff and unified organization. They were only scattered religious activities. Fairy tales and techniques are the direct sources of Dan Ding Taoism. The doctrine of immortality is the core of the entire Taoism, so it is closely related to the birth of Taoism.

Third, the ideology of the Yellow Emperor Taoism: At the end of the Qin Dynasty, society became chaotic, with the brutal policy of Legalism, which made the social rule extreme. Yellow Emperor Taoism Thought "Unconditioned Purity" became popular and flourished. The Yellow Emperor Taoism school is said to have been founded by Doan Van Tu, and ancient Chinese books do not specify this character. Van Tu's biography is only recorded in the Han book - "Nghe Van Chi", under the caption "Lao Tzu's disciple", without mentioning the author's full name and hometown" [3]. Determining the exact time and location of the appearance of the Yellow Emperor Taoism sect is still controversial. The Yellow Emperor Taoism thought on the restoration, consolidation, and development of the monarchy and the economy of the Han Dynasty has begun to have positive effects. As a result of the ruler's initiative, Yellow Emperor Taoism thought was more and more widely spread among all classes of people, later people considered Lao Tzu as their ancestor, taking the Tao Te Ching as the classic.

\subsection{Research Perspectives on Taoism with Vietnamese Mother Goddess Worship}

Being in the flow of the history of thought, like many other ideologies and religions, Taoism has influenced the cultures of countries around the world. The book Outline of Vietnamese cultural history [4], discusses the influence of Taoism in Vietnamese culture. In the book, the author used Chapter II to write about Taoism such as the introduction of Taoism, a brief overview of the process of spreading Taoism into Vietnam, some features of the position of Taoism in the cultural life of Vietnamese people in ancient and medieval times as well as the integration of Taoism with Vietnamese culture. However, when it comes to the birth of Taoism in China; The position of Taoism in the cultural and ideological life of Vietnamese people in the ancient and medieval times still lacks convincing arguments, and some issues have not been clarified. For example, in the first section (I), when presenting the birth of Taoism, the author stated: Section 1. Lao Tzu - the enlightened philosopher of one of the great schools in China. In this section, the author again affirmed: a Lao Tzu through the records of the great historian Sima Thien; b, the main contents of the Tao Te Ching; some aspects of early Taoism. Section 2. Taoism of Zhuang Tzu. Section 3. Religiousization of Taoism and the birth of Taoism in China. With such a presentation, it will mislead readers: the thought of Lao Tzu and Zhuang Tzu is the direct source of the birth of Chinese Taoism. In the brief section on spreading Taoism, some features about the position of Taoism in the cultural and ideological life in Vietnam in the Ancient - Middle Ages, the author has not clarified the importance of Taoism in the Three Religions. The author believes that, in both the Tran and post-Le dynasties, Taoism still has a firm position in the spiritual life of the people.

According to the book "The basis of Vietnamese culture" [5], the author mentioned "Taoism and Vietnamese culture". In this section, the author presents the introduction and development of Taoism in Vietnam, but only in brief with the basic ideas. The book does not provide much about the main 
content of Taoism, and the content is sometimes inaccurate, lacks coherent arguments.

The book Vietnamese Cultural Identity [6] discusses the relations between Taoism and Vietnamese beliefs. Chapter X and Chapter XI of this book briefly describe Chinese Taoism, Vietnamese beliefs, and contact with Chinese Taoism. The book also briefly presents the history of Chinese Taoism, demonstrating why Vietnamese beliefs have had a considerable change compared with the original Chinese Taoism. The author has discussed Mother Goddess worship belief. However, he has not analyzed the relations between this belief with Taoism. Beliefs are an important part of Vietnam's traditional culture. Here, the belief not only manifests itself in the form of a ritual, but it also contains many profound meanings about human life, origin, the lifestyle that every Vietnamese family still holds today.

The book "Vietnamese Beliefs" [7], discusses the beliefs of the Vietnamese people. The book has provided readers with profound and concise work about the beliefs of the Vietnamese people in the field of religion in the past and at present. The book has provided the author of this thesis with a system of rich customs of Vietnam, helping the author to discover aspects of the ingenious combination of rituals, dogmas, and rules of religions (including Taoism). It makes the author partially understand the worldview, the life view of the ancestors, the seemingly "gone" customs. It will be helpful to those who want to discover the values of the country.

A typical folk belief, very unique to the Vietnamese people, has been admired by our people, that is the belief of Mother Goddess worship. Belief in Mother goddesses has helped Vietnamese people to deify natural and human phenomena into gods. The Mother Goddess is the superior object of the belief called the Mother Goddess worship. In the polytheistic belief system of the Vietnamese, Mother Goddess worship has features not only in terms of the object of worship but also in the form of rituals. There have been many research works on this particular religion of our nation.

The study "Mother Goddess Worship Belief, its origin, form, and text of adoration" [8] has explained the origin of Mother Goddess worship and raised the criteria for the image of the Mother Goddess. It has mentioned the forms of worship of Mother Goddesses, and at the same time, pointed out superstitious phenomena and solutions to limit this phenomenon. The study discovered Chau Van singing as a unique cultural and artistic type besides other types of folk songs. The study has made positive contributions to the process of perceiving a very unique indigenous folk belief of Vietnam.

The book "Taoism and its manifestations in Vietnamese folk beliefs" [9] directly discussed the relations between Taoism and Vietnamese folk beliefs. In addition to the section on Taoism, among three beliefs discussed by the author (ancestor worship, village's tutelary God worship, and Mother goddess worship), this study has not analyzed the relations between Taoism with Mother Goddess Worship.

In the book "Vietnamese people's belief in Mother Goddess worship" [10], the author analyzed the origin, process of formation, and development of Mother Goddess worship, and forms of Mother Goddess worship in the daily life of Vietnamese people. However, this book has not discussed the effects of Taoism in the Vietnamese mother goddess worship.

In general, most of these books have discussed Taoism, the process of Taoism spreading into our country, but there is still a lack of unity such as the first organization of Taoism, characters, lineage relationships, and Taoist sects. Particularly about "Taoism and its manifestations in some folk beliefs of the Vietnamese people" mentioned very little, mainly presented two issues separately: activities of folk beliefs - Taoism, and state it from a cultural point of view. Except for Vu Hong Van's book, there have been studies on Vietnamese folk beliefs through contact with Taoism (but not an in-depth analysis of the relationship with Mother Goddess belief). This issue is a great recommendation for the author when embarking on research on this topic.

In addition, there are many other research works related to the author's topic, which are: Vietnamese culture at the peak of Dai Viet [11]; Legend of the Holy Mother Lieu Hanh and the cultural heritage of Phu Day [12]; Vietnamese culture explores and ponders [13]; Approaching Vietnamese folk beliefs [14], these authors have researched and clarified some aspects of Taoism and Vietnamese mother goddess worship.

The research results of the previous generations are undeniable, and the selective acquisition of those results is necessary. The author has tried to approach the issue based on a Marxist and philosophical methodology to study the main contents and characteristics of Chinese Taoism and Taoism with Vietnamese mother goddess worship beliefs.

\section{Results and Discussion}

\subsection{Research Results on the Influence of Taoism on Vietnamese Mother Goddess Worshipping Belief}

Firstly, the study finds out the influence of Taoism on the system of Mother Goddess worships in Vietnam. When Taoism came into Vietnam, a fairy pedigree was promoted, and the need to institutionalize the "paradise" of the Mother goddess was met. Since then, the belief in Mother Goddess worship has been quickly absorbed to form a paradise of its own. It can be said that "Mother goddess worship is where Taoism manifests its greatest influence [6]. However, Vietnamese mother goddess worship is not a religion. Vietnam's mother goddess worshiping system is still fragmented, lacking a pontiff and a church. Therefore, Mother goddess worship of the Vietnamese people is a belief only. The contact of Mother Goddess worship with Taoism reflected in the similarity in the concept of the goddess system of the mother goddess worship belief.

During the development of the belief in Mother Goddesses worship, the phenomenon of borrowing and adapting to suit the minds of Vietnamese people has taken place. It is not a baseless collection or the process of copying the original values of religions, but also a ceaseless creation of the 
Vietnamese people, creating distinguishing features of Mother Goddess worship.

If Chinese Taoism is the world of the monarchy, then the Heaven of Vietnamese Mother goddess worship belief is the world of the family. People's view of heaven is the view of children towards their mothers, and they are mother goddesses. Here, the children found the protection of their mothers.

The gods in the mother heaven reflect the different qualities of a mother, both divine and human. Mother Goddess worship does not focus on life after death, but it cares about the present life. It is expressed in prayers. The prayers are songs about many things people want in their daily lives: good weather for crops, health for everyone, happiness, and money. The content of the prayers is simple and easy to understand, which is very different from the content of other religions such as Buddhism or Christianity. The Vietnamese Mother's Heaven correctly represents a characteristic of the Vietnamese mind, which is the tolerance, warmth, and protection of a mother with her beloved children. It accepts all religions, all trends, all myths, as long as it doesn't go against that mentality of the Vietnamese. "They have successfully conceptualized a very diverse belief, and at the same time integrated many other beliefs according to the four requirements of the national consciousness in the love of a mother. It is the Chineseization of the form of goddess worship, the personification of the four natural forces that determine the lives of the agricultural inhabitants: weather, water, trees, and earth [6].

Second, the influence of Taoism on the forms of worship and the concept of life in Mother Goddess worship belief. The expression of Taoism in Mother Goddess worship belief is also reflected in the theory of this belief. The theory of Mother goddess worship is expressed in the images of the mother goddesses, their clothes, and the "genealogy" of the Mothers. The color of their clothes is the expression of the Five elements. The color of clothes that Mother Goddess of Heaven wear is red, Mother of Water is black, Mother of Mountain and Forests is white and black, Mother of Earth is yellow. As the section on ancestor worship said, this is also a phenomenon from primitive times that is still left over, that is, philosophical thinking has not separated from mythological thinking, or vice versa, it is sacred thinking about gods spirituality must end in philosophical thinking. Therefore, as in many other worships, Mother goddess worship also manifests a creative philosophy.

The Three Palaces, the Four Palaces, Ten Holy courtiers, Ten Holy Princes, Five Element Holy Courtiers, Ten Water Gods, Four Palaces of Tien Co, etc. in the genealogy of Mother worship also have critical philosophical meanings. Mothers, of course, are people worshipped like gods, fairies in heaven. However, these fairies came down to earth, reincarnated, and were born human. The person who appears in heaven and earth has a relationship of heaven - earth man. Heaven - earth - man is enough to say the number three; "Three palaces", "Three thrones" is to make Mother full of three such as "Three Worlds", "Three Gods of Taoism",
"Three Gods of Buddhism", "Trinity God", etc. The number 3 is a number indicating enough yin and yang (number 1 is yang, number 2 is yin). From the philosophical point of view of dialectical materialism, it is the unity between two opposites, the driving force for the development of things.

Four Palaces include Mother Goddess of Heaven, Mother goddess of Mountains and Forests, Mother goddess of Water, and Mother Goddess of Earth. As mentioned above: Mother Goddess of Heaven is fire; Model Goddess of Mountain and Forest is metal and wood; Mother Goddess of Water is water, Mother Goddess of Earth is earth. We will see this phenomenon in the construction of Mau Lieu Hanh's tomb later, the tombstone is taken from Ngu Hanh Son (Da Nang), to represent the five elements forming the sacred symbol for the tomb.

The expression of Vietnamese philosophy in Mother Goddess worship is also reflected in the worship of the god of time. The worship of "Twelve Holy Courtier" is to represent 12 "Earthly branches"; Worshiping "Ten Holy Princes", "Ten Holy masters" is the expression of 10 "Heavenly Stems". "When the country was ruled by mandarins, the people who executed the orders of the Mother goddesses are five mandarins according to the Five Elements theory." This is shown in "Five Elements Holy Courtiers", "The Five Mandarins", "Five Tiger Mandarins".

Explaining the presence of both male and female gods in the god system of Mother Goddess worship, researchers have hypothesized that: because the ancient Vietnamese society followed the matrilineal system, women should hold an important position in society; however, women only gain power when they are married. Therefore, men are also considered to have an important role in life and they are also worshiped.

A special part of the Mother Goddess religion is the writings, that is, the words that transcribe the teachings of the gods into the people through the mediums. This is also one of the manifestations of Taoism in Mother Goddess worship. The contents of the writings are just moral teachings on how to be a human according to the Vietnamese mind, such as love the Fatherland, take care of the family, protect the core of being a human, and protect the values left by the ancestors, avoid the woes of life. There is a Mother - The mother of the source of life, always tolerant and caring for her children. The system of gods is only an expression of her attributes. As for the phenomenon of Mother Goddess Lieu Hanh, a legend of Mother Goddess Lieu Hanh appeared, perfecting the philosophy of Mother goddess worship in ancestor worship and god worship of Vietnamese people. Mother Lieu Hanh is worshiped by our people as the mother of the world, ranked as the "four immortals", on par with Saint Giong, Saint Tan Vien Son, and Chu Dong Tu - the characters ascribed to the people by the people. supernatural power, but still contains mundane elements, very Vietnamese. Like many other religions, it shows the relationship between heaven - earth - man, as described above. In the Mother Goddess worship of Vietnamese people, the image of the "Three thrones" of the Mother Goddess is put on the highest 
throne in the Mother goddess shrine.

To increase the sacredness of the mother goddesses, people also deified some historical figures such as the Eighth Courtier was the General of Hai Ba Trung who fought against Ma Vien aggressor. Mr. Hoang That Le Luu had merit in fighting the Ming invaders; Mr. Hoang Doi in Lach Truong openly cleared the land. At the same time, over time and the concept of folk beliefs did not have a standard, so other sacred symbols were also included in the Mother shrine such as Jade Emperor, Southern Cross, Big Dipper, taking care of life and death put in Palace. Or in Tay Ho, there is an altar to worship the Goddess of Mercy. Or like Mrs. Chua Kho during the Ly - Tran dynasties, she was also honored as Mother Goddess Linh Tu at Ba Chua Kho temple in Bac Ninh.

\subsection{Discussing the Conservation and Promotion of the Values of the Current Mother Goddess Worship}

Firstly, in Resolution No. 25 [15], affirming that there should be forms of propaganda and education of the Party's lines and policies, the State's laws on respecting the right to freedom of belief and religion, or freedom of no religion at all. At the same time, it is necessary to propagandize for people to understand and be aware of the boundary between religious activities and superstitious activities; strictly punish those who take advantage of freedom of belief and religion to disrupt socio-political stability, disrupt public order, and divide the great national unity bloc.

Second, it is essential to improve step by step the material and spiritual life of the people. The purpose of this solution is to raise awareness about culture, science, and technology. To limit the negatives in Mother Goddess worship, it is necessary to gradually improve the people's material life, ensuring the people's needs for food, clothing, and housing. In the Ordinance on Belief and Religion [16], it is affirmed to take care of and build the spiritual life of the people, based on preserving and promoting traditional spiritual values. nice, selectively absorbing the cultural quintessence of humanity. The government shall improve the cultural and spiritual life of the people under the leadership of the Party, ensuring the people's freedom and democracy.

Third, it is necessary to build a healthy socio-cultural environment. Specifically, building a healthy cultural environment at the works of Mother Goddesses worshiping. In the book Contributing to the study of Vietnamese culture [17], establishing a healthy socio-cultural environment in the belief base has been set out into national action programs undertaken by the Ministry of Culture. However, this is a complicated issue, so it is necessary to complete each stage, with close coordination between relevant sectors from the central to local levels. To establish a healthy socio-cultural environment and preserve a culture imbued with national identity along with our nation's traditional festivals, we must know how to combine three factors: belief, culture, and ethnicity.

Fourth, the Law on Beliefs [18] affirmed the need for the strengthening of training and scientific research on beliefs, religions in general, and Mother-worship beliefs in particular.
For this solution to be implemented, we must first study the theoretical issues of the current Mother Goddess worship belief, and it is necessary to give clear and unified views on the phenomena of Mother Goddess Worship. It is essential to open more short-term classes to update information and provide knowledge about beliefs for people working in religion.

\section{Conclusion}

Vietnam is a multi-ethnic and multi-religious country with many festivals and different beliefs, reflecting the process of our nation's struggle to build and defend the country. It is the birthplace of the Red River civilization, where the belief in Mother Goddesses in general and Mother Goddesses of the Three Palaces and Four Palaces is clearly expressed.

The belief of Mother Goddess worship has long penetrated the soul and lifestyle of Vietnamese people and has become the unique cultural identity of our nation. Specifically, four conclusions can be reached as follows:

Formed for a long time, in the process of existence and development of the belief of Mother Goddess worship, it has connected with many other forms of belief and religion including.

Taoism was introduced into Vietnam very early (about the third century AD). Dung the process of spreading, Taoism has constantly affirmed its critical position in the spiritual and religious life of the Vietnamese people.

In our country, Mother Goddess worshiping has become a popular belief to all classes of people in society. Mother Goddesses are worshiped by people in many places, from rural to urban areas, from the South to the North. Since the belief of Mother Goddess worship is popular, it has attracted more and more people to believe and follow. In addition to the worshiping rituals, Mother Goddess worship also produces many cultural and artistic values, contributing to preserving many valuable cultural elements imbued with national identity.

Mother Goddess worship also meets the indispensable needs and aspirations of people's daily life. Today, when globalization is present across all countries, and our country is having profound changes in economy, politics, culture, and society, Mother Goddess worship has also had its theoretical and cognitive changes.

\section{References}

[1] Nghiem Toan (1959), Lao Tzu Tao-Te-Ching. National Ministry of Publication.

[2] Nghiem Toan (1972), Lao Tzu Tao-Te-Ching. Book II. Khai Tri Bookstore.

[3] Vietnam Institute of Social Sciences, Institute of Social Science Information (2004), Religion and modern life. Social science Publishing House.

[4] Nguyen Khac Thuan (2004). Outline of Vietnamese cultural history, Education Publishing House. 
[5] Tran Ngoc Them (2000), Cultural Foundation of Vietnam. Education Publishing House.

[6] Phan Ngoc (2002), Cultural identity of Vietnam, Literature Publishing House.

[7] Toan Anh (1992), Vietnamese beliefs, upper volume, Ho Chi Minh City Publishing House.

[8] Le Van Chuong (2004), Mother Goddess Worship (origin, form, text of adoration), ministerial-level scientific research.

[9] Vu Hong Van (2017). Taoism and its manifestations in Vietnamese folk beliefs, Hanoi: National Politics Truth Publishing House.

[10] Vu Hong Van (2020). Vietnamese Mother Goddess Worship, Hanoi: National Politics Truth Publishing House.

[11] Nguyen Dang Duy (2004), Dai Viet- Apogee of Vietnamese Culture, Hanoi Publishing House.

[12] Ho Duc Tho (2004), Legend of Holy Mother Lieu Hanh and cultural heritage Phu Day. Cultural information Publishing House.

[13] Tran Quoc Vuong (2000). Research and reflection on Vietnamese culture. Hanoi: National Culture Publishing House.

[14] Nguyen Minh San (1998), Approaching Vietnamese folk beliefs, National Cultural Publishing House.

[15] Party Central Committee (2003), Resolution No. 25-NQ/TW dated $12 / 3 / 2003$.

[16] National Assembly Standing Committee (2004), Ordinance on Belief and Religion No. 21/2004/PL-UBTVQH11 dated June $18,2004$.

[17] Nguyen Van Huyen (1995). Contributing to the study of Vietnamese culture, Vol. 1 \& 2. Hanoi: Social Science Publishing House.

[18] National Assembly, Law on Belief and Religion, No. 02/2016/QH14. 